\title{
POLSKA TERMINOLOGIA MEDYCZNA - SPOJRZENIE DIACHRONICZNE
}

SŁOWA KLUCZOWE: PROFESJOLEKT MEDYCZNY, BADANIA DIACHRONICZNE, KULTUROWY ODBIÓR CHOROBY

\section{WSTĘP}

Każdy język naturalny podlega ciągłym zmianom wraz ze zmieniającą się rzeczywistością i stanem wiedzy o jej elementach. Leksyka języka jest stale wzbogacana nowymi określeniami. Jednocześnie wiele wyrazów wychodzi z użycia. Terminologia, czyli słownictwo specjalistyczne, odnosząca się do różnych gałęzi nauki czy zawodowej działalności człowieka, stale ewoluuje z powodu rozwoju cywilizacyjnego i potrzeby nazywania wynalazków, nowych pojęć czy nowo odkrytych i zbadanych bytów. Jednak, ze względu na pełnioną przezeń funkcję - precyzyjny opis założeń danej dziedziny nauki, wyników badań, komunikacja specjalistyczna - terminologia nie powinna podlegać zmianom. Zjawiska polisemii, synonimii, homonimii w przypadku terminologii także winny być ograniczone lub wyeliminowane zupełnie, by zapewnić bezproblemową komunikację między specjalistami z danej dziedziny. Jak można zauważyć, mamy do czynienia z dwiema przeciwstawnymi tendencjami. $\mathrm{Z}$ jednej strony, terminologia zmienia się wraz z rozwojem nauki. $\mathrm{Z}$ drugiej, podejmowane są celowe działania, by zunifikować systemy terminologiczne, precyzyjnie określić zakres ich referencji i dbać o pewną stałość nazewnictwa pojęć specjalistycznych.

Język medyczny także podlega zmianom, co zostało ukazane w niniejszym artykule. Wiele z terminów używanych w połowie XIX wieku nie występuje już we współczesnej polszczyźnie. Pewna grupa terminów funkcjonuje nadal, lecz przedmiot lub zakres ich referencji uległ zmianie wraz z rozwojem nauk medycznych. 


\section{JĘZYKI SPECJALISTYCZNE I TERMINOLOGIA}

Wyodrębnienie się tak zwanych języków specjalistycznych ${ }^{1}$, funkcjonujących w ramach i w oparciu o języki ogólne, jest ściśle powiązane z rozwojem poszczególnych dziedzin nauki oraz ze zmianami sposobu produkcji dóbr konsumpcyjnych (rewolucja przemysłowa, mechanizacja produkcji, wynalazki itp.). Można zaryzykować stwierdzenie, że nie istnieją byty nienazwane. Nawet jeśli dany przedmiot, zjawisko lub czynność nie posiada swej nazwy w jednym języku, w innym z pewnością będzie funkcjonowało odpowiednie określenie. Dynamiczny rozwój nauki i przemysłu wymagał ukucia terminów opisujących nowo odkryte elementy badanej rzeczywistości fizycznej oraz wytwory działalności ludzkiej, na przykład wynalazki. Skalę rozwoju języków specjalistycznych opisują słowa Jana W. Sarny: „Na terenach nauk szczegółowych rozrasta się do niespotykanych rozmiarów współczesna wieża Babel. W związku ze zróżnicowaniem założeń metodologicznych oraz pogłębiającą się specjalizacją - pojawiają się hermeneutyczne języki wąskich dyscyplin" [Sarna 1997: 50]. Mimo swej rozległości referencyjnej język nauki musi opisywać przedmiot badań i uzyskane wyniki w sposób precyzyjny, niebudzący wątpliwości co do intencji autorów; wymaga uściślenia i ujednolicenia znaczeń.

Zaproponowano wiele definicji języka specjalistycznego w zależności od przyjętych kryteriów oraz perspektywy badawczej. Przykładowo, w Stowniku terminologii językoznawczej znajdziemy następującą definicję, przy czym, co należy zaznaczyć, jego autorzy używają określenia ‘język specjalny’, a nie 'specjalistyczny’: „Języki specjalne (jako języki grup społecznych) różnią się (...) swym stosunkiem do języka ogólnego, zachowują bowiem jego system gramatyczny, a zmieniają tylko słownictwo, którego elementy są zapożyczone z języków obcych" [Gołąb, Heinz, Polański 1968]. Autorzy wspomnianego słownika przyjmują perspektywę socjolingwistyczną, traktując język specjalistyczny jako język „grup społecznych”. W publikacji Języki specjalistyczne. Słownik terminologii przedmiotowej, wydanej pod redakcją Jerzego Lukszyna, zawarto szerszą definicję, uwypuklającą funkcję języka specjalistycznego. Język specjalistyczny to

skonwencjonalizowany system semiotyczny, bazujący na języku naturalnym i będący zasobem wiedzy specjalistycznej. Język specjalistyczny wykorzystywany jest w komunikacji zawodowej do porozumiewania się tylko w odniesieniu do określonych tematów specjalistycznych i może być scharakteryzowany jako: 1) narzędzie pracy zawodowej, 2) narzędzie kształcenia zawodowego, 3) wskaźnik rozwoju cywilizacyjnego" [Lukszyn 2002: 48].

Natomiast Sambor Grucza [2007] w koncepcji języka specjalistycznego podkreśla rolę użytkowników - specjalistów z konkretnych dziedzin. Każdy z nich posługuje się swoimi indywidualnym językiem - idiolektem. Logiczna suma idiolektów

${ }^{1}$ Języki specjalistyczne określane są także mianem branżowych, specjalnych, zawodowych czy sektorowych. Podczas tegorocznej konferencji zorganizowanej przez Ośrodek Rozwoju Edukacji, której tematem przewodnim były właśnie języki specjalistyczne, użyto także sformułowania „języki do zadań specjalnych". Pod takim samym tytułem ukazał się tematyczny numer Języków Obcych w Szkole 3/2016. 
wszystkich badanych osób stanowi polilekt. Oczywiście możemy mówić o polikletach naturalnym, czyli o językach faktycznie istniejących oraz polikletach standaryzowanych bądź skodyfikowanych. Należy jednak zastanowić się, czy możliwe jest odtworzenie i całościowe opisanie (np. stworzenie korpusu) naturalnego polilektu danej grupy specjalistów. Wielość koncepcji oraz problemy definicyjne doprowadziły niektórych badaczy do konkluzji, iż język specjalistyczny to byt nieopisywalny, który wymyka się próbom analizy [Martin 1984, za: Gajewska, Sowa 2014].

W przypadku języków specjalistycznym nośnikiem znaczeń jest tak zwana leksyka specjalistyczna bądź terminologia (termin częściej używany w literaturze przedmiotu). Termin to ,znak językowy (wyraz lub połączenie wyrazowe) wchodzący w skład słownictwa specjalistycznego i przeciwstawiany wyrazom i połączeniom wyrazowym języka ogólnego" [Lukszyn 2002: 137]2. Terminy charakteryzuje specjalizacja (używane są w specyficznych sytuacjach, przez określonych użytkowników), konwencjonalność (powstaje w wyniku celowej działalności określonej grupy zawodowej), systemowość (jest częścią szerszego systemu), ścisłość i jednoznaczność, neutralne nacechowanie emocjonalne i stylistyczne [Lukszyn 2002: 137]. Teoretycznie przynajmniej, w przypadku terminów, ograniczone są zjawiska polisemii i synonimii.

Jak piszą Bronisława Ligara i Wojciech Szupelak [2012: 64], „aby sprecyzować znaczenie terminu, nie można uciekać się ani do kontekst (...), ani do synonimów, należy natomiast znać dokładną definicję terminologiczną tego termin. I tutaj istotna - a właściwie najważniejsza - okazuje się wiedza encyklopedyczna". Innymi słowy, termin ma ściśle określony przedmiot referencji, treść pojęciowa do której się odnosi jest precyzyjnie definiowalna [por. Gonigroszek 2016]. Weźmy za przykład termin medyczny (a także używany w biologii i naukach pokrewnych) - 'diploid', czyli komórka lub organizm zawierający dwa jednakowe (homologiczne) zespoły chromosomów, czyli diploidalną (podwójną) liczbę chromosomów (zob. Trząski [2005]). Jak łatwo zauważyć, przedmiot referencji jest wyraźnie sprecyzowany i zdefiniowany. Niestety, nie zawsze w obrębie terminologii zjawisko polisemii, synonimii czy homonimii jest wyeliminowane całkowicie. Przykładowo termin 'luteina' odnosi się zarówno do hormonu produkowanego przez ciałko żółte w jajnikach i łożysku, jak i naturalnego żółtego barwnika obecnego w roślinach. W rzeczywistości w tym przypadku mamy do czynienia z dwoma odrębnymi terminami (homonimy), których zakresy referencji nie pokrywają się. Jednak osoba niebędąca specjalistą może myśleć, że ma do czynienia z jedną i tą samą substancją zwaną 'luteiną'.

Język medyczny winien podlegać wyjątkowej unifikacji (ujednolicenie określeń) i puryfikacji terminologicznej (eliminacja wieloznaczności, homonimii), gdyż błędne użycie terminu, na przykład w dokumentacji medycznej, może decydować o życiu i zdrowiu człowieka. Znaczenie terminu także nie powinno ulegać zmianie.

${ }^{2}$ Podobnie jak w przypadku pojęcia języka specjalistycznego zaproponowano szereg definicji terminu. Niniejszy artykuł nie ma na celu przedstawienia stanu badań nad językami specjalistycznymi czy terminologią, a raczej ukazanie zmian w obrębie terminologii medycznej czy przedmiotu ich referencji. Z tego powodu ograniczono się do zacytowania jednej ogólnej definicji terminu. 
Dorota Gonigroszek [2016], odwołując się do założeń językoznawstwa kognitywnego, stwierdza, że termin przywołuje relatywnie stałą reprezentację mentalną (pojęcie, domenę, matrycę domen), która swą strukturą przypomina kategorię klasyczną. Gdyby znaczenie terminów zmieniało się tak szybko, jak znaczenie niektórych wyrazów języka ogólnego, jakakolwiek komunikacja specjalistyczna nie byłaby możliwa ze względu na problemy interpretacyjne. Z drugiej jednak strony, nauka nie stoi w miejscu. S. Winogradow i A. Kuźmin [1951: 22-23] celnie trafiają w sedno problemu:

Pojęcia będące odbiciem świata obiektywnego powstają jako wynik działalności myślowej wielu ludzi. Odznaczają się one stałością i jak każde nagromadzone przez ludzi doświadczenie przekazywane są przekazywane są przez jednego człowieka drugiemu. Stałość pojęć o których tu mowa, jest rozumiana historyczni, to znaczy pojęcia są stałe w danym okresie, według danego stadium rozeznania. W związku z rozwojem życia i poznania zmieniają się one stale. W toku zdobywanego doświadczenia, w miarę jak ludzie głębiej poznają świat materialny, treść pojęć wzbogaca się nowymi cechami, a odrzuca się cechy przestarzałe. Pojęcia jednak zmieniają się nie tylko dlatego, że ludzie głębiej wnikają w istotę zjawisk, lecz także dlatego, że same te zjawiska z biegiem czasu ulegają zmianie.

W konsekwencji rozwoju poszczególnych gałęzi nauki terminy zmieniają swój przedmiot i zakres referencji (treść pojęciowa, którą przywołują ulega zmianie) lub też, co zdarza się częściej, wychodzą one z użycia, zastępowane przez nowe określenia. Ta druga strategia zdaje się być bardziej odpowiednią w przypadku nauk medycznych, gdyż pozwala na eliminację barier komunikacyjnych i błędów interpretacyjnych. Zachowanie terminu w jego pierwotnej postaci mimo zmiany znaczenia pozwala w pewnym stopniu zobrazować rozwój nauki (przemiany w sposobie myślenia, rozumienia procesów i zjawisk).

René Descarte, który w traktacie De homine z 1662 roku dokonał wyjątkowo precyzyjnego opisu anatomii i fizjologii człowieka, jak na tamte czasy, wierzył, że funkcją szyszynki jest łączenie ciała z umysłem. Termin pozostał w użyciu, stan wiedzy zmienił się radykalnie (szyszynka - łac. Corpus lineale, franc. Pinéale). Wiele podobnych przykładów, nie tylko z dzidziny medycynych, opisanych zostało w Krótkiej historii nauki autorstwa Williama Bynuma [2016].

W kolejnej części niniejszego opracowania przedstawiono szereg terminów medycznych używanych ponad sto lat temu w języku polskim. Zostały one ustalone na podstawie publikacji Medycyna ludowa ... z 1860. Większość z nich wyszła już z użycia, a poglądy na przedmiot referencji (choroba, objaw) uległy radykalnym zmianom.

\section{Polska terminologia Medyczna Z POŁOWY XIX WIEKU}

Omówione terminy medyczne zostały ustalone na podstawie publikacji o charakterze naukowym - Medycyna ludowa czyli treściwy poglad na środki ochronne, poznawanie i leczenie chorób. Poradnik lekarski. Poradnik autorstwa A. Simona 


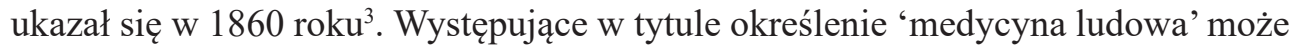
być obecnie mylnie interpretowane. Przymiotnik 'ludowa' oznacza tutaj 'ludzi/odnosząca się do ludzi' (w odróżnieniu, na przykład od praktyk medycznych odnoszących się do zwierząt/medycyny zwierząt). W publikacji przedstawiono liczne schorzenia wraz z towarzyszącymi im objawami oraz sposoby ich leczenia. Poradnik ten ukazuje stan ówczesnej wiedzy medyczny (zasady utrzymania higieny, źródła i przyczyny chorób, pożądany styl życia), może być zatem cennym źródłem informacji dla historyków, kulturoznawców, a także językoznawców zainteresowanych diachronicznymi przemianami zachodzącymi w języku.

Najmniej poznanym i rozumianym obszarem funkcjonowania ludzkiego organizmu zdaje się być sfera mentalna (układ nerwowy; zaburzenia leczone współcześnie przez lekarzy neurologów lub psychiatrów). W Medycynie ludowej... pojawiają się następujące terminy i charakterystyki schorzeń (zachowano oryginalną pisownię):

- hysterya - „cierpienie nerwów, odznaczające się objawami nerwowemi pojedynczo albo w formie ataków połączonych z utratą przytomności i konwulsjami" [Simon 1860: 236]. Co ciekawe, to schorzenie przypisywane jest wyłącznie kobietom, a jego przyczyn należy szukać w nieudanym życiu uczuciowym (,wzruszenia moralne”, „miłość zawiedziona”, „nadużycie płciowe”, „zaburzenia periodu”). Simon [1960: 237] radzi, by „kobietę mającą atak nerwowy umieścić w miejscu takim, aby nie mogła się zranić, rozebrać, chlusnąć w twarz zimną wodą, dać wąchać eter" lub, co ważniejsze, zapewnić różne rozrywki, a najlepiej wydać za mąż. We współczesnej polszczyźnie rzeczownik >histeria odnosi się do „bardzo gwałtownej i przesadnej reakcji uczuciowej" [Stownik języka polskiego PWN - wersja internetowa]. Histeria w oznaczeniu jednostki chorobowej w języku medycznym nie funkcjonuje ${ }^{4}$.

- hypokondrya - „, choroba mężczyznom właściwa, tak jak u kobiet hysterya” [Simon 1986: 237]. Objawami tego schorzenia mają być, między innymi „usposobienie smutne”, „stronienie towarzystwa”, „utrata siły muskularnej”, „niechęć do pracy”, „brak apetytu”. Leczenie polega na zmianie stylu życia (podróże, zmiana mieszkania, unikanie wina i piwa, praca w ogrodzie). Obecnie mianem hipochondrii określa się zaburzenia psychiczne polegające na przesadnym i nieuzasadnionym przekonaniu o własnej chorobie i nadinterpretacji naturalnych stanów organizmu, uznawaniu ich za symptomy przeróżnych schorzeń.

- obłęd pijacki - „rodzaj majaczenia, pochodzący z nadużycia trunków spirytualnych i fermentujących, i który oprócz zmienienia władz umysłowych sprowadza zarazem drżenie w członkach, trudności mowy i bezsenność uporną" [Simon 1860: 234]. Można przyjąć, iż obłęd pijacki to dawne określenie na majaczenie alkoholowe (łac. delirium tremens).

${ }^{3}$ Wymieniona pozycja stanowi jedyne źródło danych językowych poddawanych analizie w niniejszym opracowaniu. Z pewnością wykorzystanie innych książek, poradników, podręczników dla studentów medycyny wzbogaciłoby materiał badawczy. Jednak ze względu na wymaganą objętość artykułu oraz trudności w dotarciu do oryginalnych źródeł z połowy XIX ograniczono się do analizy jednego tylko opracowania medycznego.

${ }^{4}$ Osoby zainteresowane tą tematyką, to znaczy kulturowym i społecznym spojrzeniem na naturę zjawiska zwanego histerią, można odesłać do pracy: Historia histerii autorstwa Etienne Trillat. 
W rozdziale zatytułowanym $O$ pomieszaniu zmystów znajdziemy następujące jednostki chorobowe: Mania, Monomania, Przytępienie umysłu, Idiotyzm, Pomieszanie zmysłów z sparaliżowaniem (wszystkie odnoszą się do pewnego rodzaju „obłędu” i „ograniczenia władz umysłowych”). Warto zacytować definicję idiotyzmu, która do pewnego stopnia odzwierciedlać może społeczny stosunek do osób o obniżonych możliwościach intelektualnych:

Idiotyzm - przyrodnia nieobecność inteligencji, zwykle jest połączony z nieprawidłowym rozwojem mózgu. Przedstawia trzy stopnie: 1. Głupota, gdzie jeszcze pozostaje kilka idei i człowiek może podejmować rzeczy proste; 2. Idiotyzm, gdzie działania instynktowne mają tylko miejsce, lecz nie ma żadnego zastanowienia się; 3. Automatyzm, w nim człowiek staje się maszyną, którą trzeba poruszać ażeby co czynił; obojętny na wszelkie wpływy tak przyjemne jak i bolesne [Simon 1860: 330].

Zauważalną zasadą typologii chorób jest ich klasyfikacja ze względu na główny objaw. Bardzo często to, co we współczesnej medycynie uznawane jest za symptom, niegdyś było uważane za odrębną jednostkę chorobową. W Medycynie ludowej... znajdziemy określenia typu: Biegunka z niestrawności, Biegunka żółciowa, Biegunka kataralna, Biegunka reumatyczna, Biegunka zapalna, Biegunka nerwowa. Jak wynika $\mathrm{z}$ towarzyszących opisów, biegunka jest w opinii autora schorzeniem, a nie objawem towarzyszącym danej chorobie. Analogicznie w publikacji znajdujemy następujące terminy: Suchoty, Suchoty płucne, Suchoty gardlane, Suchoty krzyżowe. Przy czym ogólny termin suchoty odnosi się do „rozmaitych stanów chorobliwych przy których zwalnia ciało i siły nikną (...)" [Simon 1860: 215]. Jak należy mniemać, na podstawie analizy wymienionych objawów, Suchoty płucne odnoszą się do gruźlicy.

Simon omawia szereg schorzeń zwanych Gorączkami, ponownie dokonując klasyfikacji chorób na podstawie głównego objawu, co znajduje swe odzwierciedlenie w przyjętej strategii nominacji schorzeń: Gorączka szluzowa, Gorączka zgniła, Gorączka wysypkowata, Gorączka trawiąca, Gorączka przepuszczająca prosta, Gorączka ukryta, Gorączka pierwotna.

W omawianej publikacji pojawiają się terminy, obecnie już nieużywane, które nawet na podstawie wymienionych objawów, ciężko powiązać z jednostką chorobową i jej współczesną nazwą. Przykładami są:

- karbunkut (objawy: gorączka, owrzodzenie, ból głowy, gorączka, strup gangrenowy, powstająca obszerna rana; leczenie: przystawianie pijawek, przecięcie wrzodzianki, opatrunek nasączony chloranem wapnia). Karnbunkut to dawna nazwa na ropne zapalenie torebek włosowych przechodzące na tkankę podskórną lub czyrak mnogi.

- petocie (objawy: podskórne wysięki krwi, dreszcze osłabienie; leczenie: zmiana diety na bogatszą, pełnowartościową z dużą ilością warzyw i mięsa). Obecnie stosuje się określenie petocje, czyli wybroczyny. Petocji nie traktuje się jako jednostki chorobowej, ale objaw, na przykład zaburzeń krzepnięcia krwi. Forma terminu uległa niewielkiej zmianie i pojęcie, do którego się odnosi.

- kongestyje (ogólny termin odnoszący się do ,przepełnienia jakiejkolwiek części ciała lub organu krwią" [Simon 1860: 166]. Można przypuszczać, iż w zależności 
od organu wewnętrznego mamy do czynienia z tym, co współcześnie nazywamy krwotokiem wewnętrznym bądź wylewem (np. krwi do mózgu).

- wyprzenie (występuje u noworodków, objawia się zaczerwienieniem w kroczu, pod pachami). Prawdopodobnie współczesnym odpowiednikiem terminu jest odparzenie.

- brak krwi czyli bladaczka - „Oznacza zmniejszenie się ilości prawidłowej krwi $\mathrm{w}$ ciele i powiększenie surowicy; przyczyny: krwotoki, mieszkanie w miejscach ciemnych, brak ruchu, pożywienie niedostateczne, zepsucie krwi, praca w kopalniach" [Simon, 1860: 189]. Można przypuszczać, iż współczesnym terminem na oznaczenie opisywanej choroby jest anemia.

- choroba błękitna - „Pochodzi od znacznej w ciele ilości krwi czarnej, co objawia się kolorem niebieskim skóry, osłabieniem muszkułów; skóra zimna, cieżkość oddychania, a przy tym czasowym biciem serca z obawą i omdleniem" [Simon 1860: 189]. Ciężko stwierdzić, co autor miał na myśli, pisząc o „,czarnej krwi” (żylnej, a zatem ciemniejszej od tętniczej; o zupełnie innym zabarwieniu od naturalnego?). We współczesnej literaturze medycznej pojawia się termin Choroba błękitnej skóry (łac. Methemoglobinemia) (Choroba spowodowana mutacją genetyczną. Krew nie dostarcza wystarczającej ilości tlenu do tkanek i w rezultacie powłoki skórne chorego zmieniają zabarwienie na niebieskawe). Jednak opisy objawów nie wskazują na ten sam typ schorzenia określany różnymi terminami.

- zarazek - określenie często używane na czynnik powodujący chorobę, drobnoustrój. Nie dokonuje się rozróżnienia między bakteriami i wirusami.

W poradniku Simona pojawia się wiele terminów używanych na oznaczenie jednostek chorobowych, które nadal występują we współczesnym języku medycznym, jak na przykład: białaczka, źółtaczka, złamania, odra, szkarlatyna, ospa, świerzb itp. Co jednak istotne, opis towarzyszących tym schorzeniom symptomów wskazuje na odmienny stan wiedzy od obecnego. Podawane sposoby leczenia są bardzo ograniczone, a nawet mogą być uznane za szkodliwe. Przykładowo, zaleca się stosowanie upuszczania krwi przy krwotokach. Można zatem stwierdzić, że w przypadku zacytowanych powyżej nazw chorób, termin nie uległ zmianie, natomiast treść pojęciowa, do której się odnosi, tak.

\section{WNIOSKI}

Polska terminologia medyczna uległa zauważalnym zmianom w przeciągu ostatnich 150 lat. Wiele z terminów wyszło już z użycia. Niejednokrotnie nawet ciężko ustalić, do jakiej jednostki chorobowej się odnosiły. Inne pozostały, lecz nadano im nowe znaczenia. Używając określenia z zakresu językoznawstwa kognitywnego, terminy te przywołują obecnie odmienne konceptualizacje (pojęcia, domeny, matryce domen - inaczej ustrukturyzowane systemy wiedzy). Analizy dawnych tekstów medycznych nie tylko pozwalają na rekonstrukcję ówczesnego stanu wiedzy. Ukazują zmiany językowe zachodzące przede wszystkim na poziomie leksyki. Można również badać proces nominacji pojęć pod kątem motywacji kognitywnych leżących u podłoża tego procesu. Jak można zauważyć na podstawie badanego tekstu, 
kiedyś dokonywano kategoryzacji chorób ze względu na główny objaw (chorobę utożsamiano $\mathrm{z}$ objawem), co znalazło swe odzwierciedlenie $\mathrm{w}$ tworzonych terminach. Badanie terminologii z perspektywy diachronicznej umożliwia identyfikację sposobów konceptualizacji procesów chorobotwórczych na przestrzeni wieków.

\section{Bibliografia}

Bynum W. [2016], Krótka historia nauki, przekł. Skawran K., Wydawnictwo RM, Warszawa.

Descartes R. [1989], Człowiek. Opis ciała ludzkiego, przekł. Andrzej Bednarczyk, PWN, Warszawa.

Gajewska E., Sowa M. [2014], LSP, FOS, Fachsprache... Dydaktyka języków specjalistycznych, Wydawnictwo Werst, Lublin.

Gonigroszek D. [2016], Terminologia specjalistyczna - podejście kognitywne, [w:] Interdyscyplinarność $i$ wielowymiarowość nauk filologicznych, Gonigroszek D. Stanecka A. (red.). Naukowe Wydawnictwo Piotrkowskie, Piotrków Trybunalski.

Grucza S. [2007], Od lingwistyki tekstu do lingwistyki tekstu specjalistycznego, Wydawnictwo Euro-Edukacja, Warszawa.

Języki specjalistyczne. Stownik terminologii przedmiotowej [2002], Lukszyn J. (red.) Katedra Języków Specjalistycznych Uniwersytetu Warszawskiego, Warszawa.

Ligara B., Szupelak W. [2012], Lingwistyka i glottodydaktyka języków specjalistycznych na przykładzie języka biznesu. Podejście porównawcze, Księgarnia Akademicka, Kraków.

Sarna J.W. [1997], Człowiek i filozofia, Wydawnictwo Uniwersytetu Opolskiego, Opole.

Simon A. [1860], Medycyna ludowa czyli treściwy poglad na środki ochronne, poznawanie i leczenie chorób. Poradnik medyczny, Nakładem Michała Glücksberga Księgarza, Warszawa.

Stownik terminologii językoznawczej, 1968, Gołąb Z., Heinz A., Polański K. (red.), PWN, Warszawa.

Trillat E. [1993], Historia histerii, Zakład Narodowy im. Ossolińskich, Wrocław.

Trząski L. [2005], Stownik biologiczny, Videograf, Katowice.

Winogradow S., Kuźmin A. [1951], Logika, Rakowski M., Rakowska S. (przekł.), Nasza Księgarnia, Warszawa. 